JOURNAL OF PUBLIC HEALTH FOR TROPICAL AND COASTAL REGION (JPHTCR)

Journal homepage: http:/ejournal2.undip.ac.id/index.php/jphtr/index

ISSN : 2597-4378

\title{
Spatial Analysis of Environmental Factors with the Existence of Filariasis Vectors in Brebes Regency
}

\author{
Shavira Nur Fadhilla ${ }^{*}$, Arum Siwiendrayanti ${ }^{1}$ \\ ${ }^{1}$ Department of Public Health, Semarang State University, Indonesia \\ ${ }^{*}$ Corresponding Author. Email: sdhilla5@gmail.com
}

\begin{abstract}
Introduction: Ketanggungan District is one of the endemic filariasis areas in Brebes Regency since 2016 with an Microfilaria Rate $>1 \%$. Filariasis is an infectious disease that attacks the lymph nodes caused by filarial worms and is transmitted by mosquitoes. Environmental factors can affect the transmission of filariasis, which will provide a resting place and breeding place for mosquitoes. Therefore, this research aimed to describe the existence of filariasis vectors and environmental factors that can be seen spatially.

Methods : The research was a descriptive observational/ exploratory study using Geographical Information System (GIS) approach. Data collection was carried out by entomological surveys, subject points sampling, and research objects using GPS. Data were analyzed spatially by Geographic Information Systems (GIS).

Results: Culex quinquefasciatus was the type of mosquito which had the highest distribution in Karangmalang District. The mosquitos were found at sewers, puddles, shrubs and cattle pen. The vectors can be found within a distance of $29 \mathrm{~m}$ to $2 \mathrm{~km}$ from filariasis cases.

Conclusion: Culex quinquefasciatus may be the vector of filariasis in Ketanggungan District, with the most environmental factors found in Dukuhturi Village.
\end{abstract}

Keywords: Filariasis, Environmental Factors, mosquito, Culex quinquefasciatus

Article History: Received: $8^{\text {th }}$ April 2021, Revised: 17 th June 2021, Accepted: ${ }^{\text {nd }}$ August 2021

\section{Introduction}

Lymphatic filariasis is an infectious disease that spreads in the tropics and still become a global health problem. Filariasis can affect the lymphatic system, causing chronic disability and thus creating a negative social stigma. The disease is caused by filarial nematode worms consisting of three types: Wuchereria bancrofti, Brugia malayi, and Brugia timori. ${ }^{1}$ Filariasis infection spreads through the bites of various types of mosquitoes. It shows that around 23 species from 6 genera, namely Aedes, Anopheles, Armigeres, Culex, and Mansonia mosquitoes, can be the vectors for filariasis. $^{2}$
Based on World Health Organization (WHO) data in 2020, it was known that 120 million people in the world were infected with lymphatic filariasis. There were 25 million people who suffer from venereal diseases (most commonly hydrocele), and nearly 15 million suffer from lymphedema or elephantiasis. Of the total population requiring prevention, 57\% live in the Southeast Asia Region ( 9 countries), and $37 \%$ live in the African Region (35 countries). ${ }^{1}$

Indonesia is the country with the second-highest case in Southeast Asia. ${ }^{3}$ Filariasis cases in 2018 were 10,681 spread across 28 provinces. Central Java is the province with the lowest success rate in 
reducing microfilariae of the 28 provinces, although the POPM (mass administration of preventive drugs) implementation percentage is $88.89 \% .{ }^{4}$ Based on data from the Central Java Health Profile in 2019, the number of chronic Filariasis cases in Central Java was 391 cases, with the discovery of the most filariasis cases in Brebes Regency (5 cases). ${ }^{5}$

Based on filariasis case data from Brebes Health Office, the number of cases in 2019 was 61 . The highest cases were found in Ketanggungan District with 8 cases, while other Districts like Bantarkawung and Paguyangan have 5 and 4 cases. ${ }^{6}$ Brebes Regency has become an endemic filariasis area because there were patients with leg swelling clinical symptoms since 2016 . The transmission of filariasis from animals to humans and humans to humans with mosquitoes as a vector of filariasis can increase microfilariae $(>1 \%)$.

Ketanggungan District is a fairly complex area, part of this area is a densely populated urban, but part of the area is hilly with lots of empty lands. In this district, there are many open and inundated sewage drains and midden. Thus, the potential for mosquitoes to breed and become vectors of filariasis is higher, and the transmission of filariasis increases.

In preliminary results carried out in another area of Brebes Regency in January 2020, it was found that larvae and mosquitoes were waterlogged in wastes. They were inundated in rice fields (3 points), livestock sheds (2 points), shrubs (4 points), open sewers (4 points), and puddles (3 points).

Therefore, it is necessary to carry out further research related to mosquitoes' distribution and environmental factors that support mosquitoes' presence. Environmental conditions can influence the potential of mosquitoes as the vectors for filariasis. This situation happens because mosquitoes can only survive in certain environmental conditions. Besides, environmental changes that change from time to time will affect the contribution of filariasis vector growth.

It is necessary to do area-based vector control planning using a spatial approach. The spatial distribution of filariasis vectors is a crucial stage in the planning and implementing of vector control program that is right on target. Spatial distribution using a Geographical Information System (GIS) allows the creation of visualization in the form of a map on the distribution of mosquitoes and the breeding grounds for filariasis vectors to facilitate observation by the conditions of the population and region. The purpose of this study was to describe the distribution of potential vectors of filariasis and their habitat as can be seen through mapping in endemic areas, Ketanggungan District, Brebes Regency.

\section{Methods}

This research was conducted in Ketanggungan District, Brebes Regency, especially in filariasis endemic areas, namely Ketanggungan, Dukuhturi, Karangmalang, Baros, Cikeusal Lor and Jemasih villages. This research was conducted during August - September 2020. This study was a descriptive observational/ exploratory study with Geographical Information System (GIS) approach. Entomological surveys were carried out on the potential vectors of filariasis and environmental factors in the area.

The study population was all fullgrown mosquitoes caught and the environmental factors in Ketanggungan District. The samples of the mosquito species were all mosquitoes caught at the research location. Samples of environmental factors were all potential places for mosquito breeding and resting in the research location. The mosquito samples were taken using a catching station technique. Determination of the catching station was adjusted to the characteristics of land use and mosquito bioecology. The chosen fishing point was a residential area. Meanwhile, the sampling technique for environmental factors was carried out using accidental sampling technique in each filariasis endemic village in Ketanggungan District.

The research instruments used in this study were the observational sheet and GPS device. Observational sheets were used to record mosquitoes caught based on the time and location of capture and 
environmental factors found in the study area and GPS devices to carry out digitization. The tools used in conducting the entomological survey include aspirators, flashlights, plastic cups, gauze, rubber bands, scoops, pipettes, bottles, rulers, stationery, labels, baskets, cotton pads, labels paper, sugar solution, and survey form.

The research procedure was carried out in several steps. The first step was done by determining the catching point for mosquitoes and environmental factors. Catching the mosquitoes was done by baiting them to people outside the house at night (6 PM - 6 AM). Coordinate points were also taken and samples of adult mosquitoes and larvae were sent the field to the laboratory. In the second step, all mosquitoes caught were identified using a microscope with an identification key. ${ }^{7}$ The third step was mosquito dissection by dissecting the whole body of the mosquito to find microfilariae.

Data analysis was conducted by determining the distribution of Culex $s p$, Armigeres, and Aedes sp mosquitoes which have the potential to be the vector of filariasis. Distribution of Culex $s p$, Armigeres, and Aedes sp mosquitoes were analyzed based on the time of capture, relative abundance, species frequency, dominance of mosquito species as potential vectors for filariasis and environmental factors. Relative abundance, species frequency and species dominance were calculated according to these formula ${ }^{8}$ :

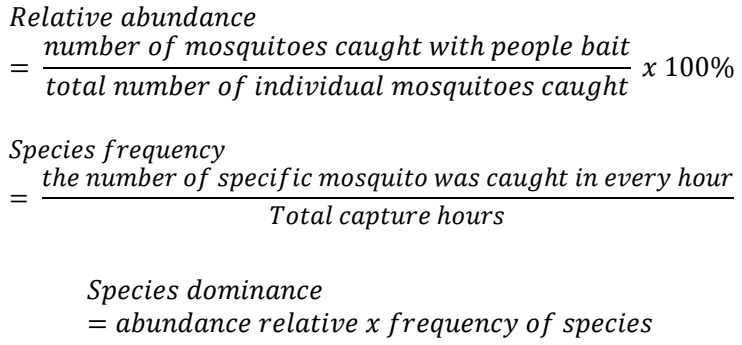

Spatial data analysis was done by collecting the coordinates of environmental factors at the research location using GPS which then were analyzed using geographic information systems (GIS). Data were displayed in the form of spatial/regional mapping.

\section{Results}

Ketanggungan District is located in the middle of Brebes Regency on a flatland of 17 meters above sea level. ${ }^{9}$ It covers $153.41 \mathrm{~km}^{2}$ consisting of rice fields 6,703.92 hectares, fields 6,696.38 hectares, and 1,940.41 hectares of settlement. Rainfall in Ketanggungan District in 2020 was $13,803 \mathrm{~mm}$ with 195 days of rainfall. ${ }^{10}$

Based on the observations (Table 1), the potential habitat types in Ketanggungan District were 43 points consisting of 5 types of breeding place. On average each village has an open sewers. The closest distance to the breeding place point in Jemasih Village was $19.61 \mathrm{~m}$ to the open sewers. The village that has many breeding places was Dukuhturi with a total of 12 open sewers and 2 puddles (fish ponds \& used boxes). On average each village has a distance of less than $200 \mathrm{~m}$ from each mosquitoes' breeding place, except Cikeusal Lor Village which has $239.5 \mathrm{~m}$ away from open sewers and has the fewest breeding place.

There were 24 resting places of mosquitoes in Ketanggungan District which had 3 types of resting place (see Table 2). The village which had the most resting places was Dukuhturi village with 4 shrubs and 1 cattle pen, Jemasih village with 1 bush, 1 shrub and 3 cattle pen. The closest distance between the sufferer's house and the resting place was found in Ketanggungan Village, with a distance of $29.7 \mathrm{~m}$ to the shrubs.

In average each village had the distance between the sufferer's house and the resting place less than $200 \mathrm{~m}$ except for Cikeusal Lor Village with the distance of $688.62 \mathrm{~m}$ to the Cattle pen and Jemasih Village with $2 \mathrm{~km}$ distance to the resting place. 
Table 1. Distribution of mosquito breeding places in Ketanggungan District, Brebes Regency

\begin{tabular}{|c|c|c|c|c|c|}
\hline Village & $\begin{array}{l}\text { Breeding } \\
\text { places }\end{array}$ & Total & $\begin{array}{c}\text { Average } \\
\text { Distance } \\
(\mathrm{m})\end{array}$ & $\begin{array}{c}\text { Closest } \\
\text { Distance } \\
(\mathrm{m})\end{array}$ & $\begin{array}{c}\text { Farthest } \\
\text { Distance } \\
\text { (m) }\end{array}$ \\
\hline \multirow{2}{*}{$\begin{array}{l}\text { Ketanggungan } \\
\text { (sufferer 1) }\end{array}$} & $\begin{array}{l}\text { Open Sewers } \\
\text { (not flowing) }\end{array}$ & 8 & 150.70 & 44 & 436.6 \\
\hline & $\begin{array}{l}\text { Open Sewers } \\
\text { (flowing) }\end{array}$ & 2 & 253.92 & 126 & 381.85 \\
\hline $\begin{array}{l}\text { Ketanggungan } \\
\text { (sufferer 2) }\end{array}$ & Puddle (pool) & 1 & - & 53.44 & - \\
\hline \multirow[b]{2}{*}{ Dukuhturi } & $\begin{array}{l}\text { Open Sewers } \\
\text { (not flowing) }\end{array}$ & 12 & 485.22 & 128.83 & 1043 \\
\hline & $\begin{array}{c}\text { Puddle } \\
\text { (fish ponds \& } \\
\text { used boxes) }\end{array}$ & 2 & 99.67 & 57.26 & 142.08 \\
\hline \multirow{2}{*}{ Karangmalang } & $\begin{array}{l}\text { Open Sewers } \\
\text { (not flowing) }\end{array}$ & 6 & 261.015 & 69.89 & 861.03 \\
\hline & $\begin{array}{c}\text { Puddle } \\
\text { (used bucket) }\end{array}$ & 1 & - & 105.90 & - \\
\hline Baros & $\begin{array}{l}\text { Open Sewers } \\
\text { (not flowing) }\end{array}$ & 8 & 224.11 & 41.15 & 648.6 \\
\hline Cikeusal Lor & $\begin{array}{l}\text { Open Sewers } \\
\text { (not flowing) }\end{array}$ & 1 & - & 239.5 & - \\
\hline Jemasih & $\begin{array}{l}\text { Open Sewers } \\
\text { (not flowing) }\end{array}$ & 2 & 905.305 & 19.61 & 1.791 \\
\hline
\end{tabular}

Table 3 shows that there were five species of mosquitos in Ketanggungan District that were caught around the houses where there were shrubs and cattle pens.
The number of mosquitoes caught was 955. The mosquito dissection results were negatives, which mean no microfilaria found in the mosquito's body.

Table 2. Distribution of mosquito resting places in Ketanggungan District, Brebes Regency

\begin{tabular}{cccccc}
\hline Village & $\begin{array}{c}\text { Environmental } \\
\text { Variables }\end{array}$ & Total & $\begin{array}{c}\text { Average } \\
\text { Distance } \\
\mathbf{( m )}\end{array}$ & $\begin{array}{c}\text { Closest } \\
\text { Distance } \\
\mathbf{( m )}\end{array}$ & $\begin{array}{c}\text { Farthest } \\
\text { Distance } \\
\mathbf{( m )}\end{array}$ \\
\hline $\begin{array}{c}\text { Ketanggungan } \\
\text { (sufferer 1) }\end{array}$ & Shrubs & 3 & 246.99 & 29.7 & 550.09 \\
\hline $\begin{array}{c}\text { Ketanggungan } \\
\text { (sufferer 2) }\end{array}$ & - & - & - & - & - \\
\hline Dukuhturi & Shrubs & 4 & 452.5 & 47.64 & 961.8 \\
\cline { 2 - 6 } & Cattle Pen & 1 & - & - & 427.35 \\
\hline Karangmalang & Shrubs & 2 & 101.39 & 101.39 & - \\
\cline { 2 - 6 } Baros & Cattle Pen & 1 & - & 73.29 & - \\
\cline { 2 - 6 } & Shrubs & 2 & 158.95 & 91.89 & 226.02 \\
\hline Cikeusal Lor & Cattle Pen & 2 & 143.65 & 61.23 & 226.02 \\
\hline \multirow{2}{*}{ Jemasih } & Cattle Pen & 4 & 463.76 & 323.08 & 688.62 \\
\cline { 2 - 6 } & Shrubs & 1 & - & 111.751 & - \\
\cline { 2 - 6 } & Bush & 1 & - & 389,198 & - \\
\hline
\end{tabular}

It was found that the species of mosquitoes found in Ketanggungan District were Culex quinquefasciatus, Culex vishnui, Culex tritaeniorhyncus, Aedes aegypti, and Armigeres. Mosquito breeding sites were found around the fishing ponds, open sewers, open and non-flowing sewer 
and fishing ponds. These places were the breeding places for mosquitoes. ${ }^{11}$

Table 1 shows that mosquitoes are primarily found in the research location close to thickets. This is due to the anthropophilic nature of mosquitoes. Shrubs are a strategic place for mosquitoes to rest and breed. ${ }^{12}$

Environmental conditions play a significant role in the presence of mosquitoes during capture. Mosquito density is affected by temperature and humidity. Physical environmental conditions in Ketanggungan District are ranging from $19-31.7^{\circ} \mathrm{C}$ with the humidity of $59-89 \%$. According to Anggraini, temperature and humidity affect the presence of mosquitoes. The optimal air temperature for mosquitoes ranges from $25-30^{\circ} \mathrm{C}$; moreover, humidity can affect the presence of mosquitoes with a minimum limit of $60 \%$. Humidity higher than $60 \%$ will make mosquitoes active and often bite humans, so that the potential for filariasis transmission will increase. ${ }^{13}$

Table 3. Distribution of Caught Mosquitoes in Ketanggungan District, Brebes Regency, Central Java

\begin{tabular}{|c|c|c|c|c|c|}
\hline \multirow{2}{*}{ Village } & \multirow{2}{*}{ Species of Mosquitoes } & \multicolumn{2}{|c|}{ The Mosquito Caught } & \multirow{2}{*}{ Total } & \multirow{2}{*}{ Results } \\
\hline & & Bush & Cattle Pen & & \\
\hline Ketanggungan & $\begin{array}{l}\text { Cx. quinquefasciatus } \\
\text { Aedes aegypti }\end{array}$ & $\begin{array}{c}110 \\
1\end{array}$ & - & 111 & Negative \\
\hline Dukuhturi & $\begin{array}{l}\text { Cx. quinquefasciatus } \\
\text { Aedes aegypti }\end{array}$ & 153 & $\begin{array}{c}68 \\
1\end{array}$ & 222 & Negative \\
\hline Karangmalang & $\begin{array}{l}\text { Cx. quinquefasciatus } \\
\text { Aedes aegypti } \\
\text { Armigeres sp }\end{array}$ & $\begin{array}{c}223 \\
1 \\
3\end{array}$ & $\begin{array}{c}102 \\
0 \\
1\end{array}$ & 330 & Negative \\
\hline Baros & Cx. quinquefasciatus & 115 & 123 & 238 & Negative \\
\hline Cikeusal Lor & Cx. quinquefasciatus & - & 20 & 20 & Negative \\
\hline Jemasih & $\begin{array}{l}\text { Cx. quinquefasciatus } \\
\text { Cx. vishnui } \\
\text { Cx.tritaeniorhynchus }\end{array}$ & $\begin{array}{c}16 \\
16 \\
2\end{array}$ & - & 34 & Negative \\
\hline & Total & 640 & 315 & 955 & \\
\hline
\end{tabular}

Table 4 shows that the highest relative abundance was $C x$. quinquefasciatus (97.38), then $C x$. vishnui (1.68), Armigeres (0.42), Aedes aegypti (0.31) and Cx. tritaeniorhynchus (0.21). The type of mosquito with the highest frequency was Culex quinquefasciatus (0.75). Dominance numbers can illustrate the substantial role of the mosquito population. Cx. quinquefasciatus (73.04) was the mosquito that dominates in this region.
Dominance numbers can describe the actual mosquito population density in an area compared to other density parameters. The species dominance factor is one of the factors taken into account to estimate the mosquitoes' species potential to become the vectors of disease transmission. Some other dominant mosquito species were $C x$. vishnui (0.14), $C x$. tritaeniorhynchus (0.02), Armigeres (0.07), and Aedes aegypti (0.08) with their respective frequencies presented in table 4. 
Table 4. The Distribution of Relative Abundance, Frequency and Dominance of
Mosquitoes Caught in Ketanggungan District, Brebes Regency

\begin{tabular}{lccc}
\hline Types of Mosquitoes & $\begin{array}{c}\text { Relative } \\
\text { Abundance }\end{array}$ & Frequency & Dominance \\
\hline Cx. quinquefasciatus & 97,38 & 0,75 & 73,04 \\
\hline Cx. vishnui & 1,68 & 0,08 & 0,14 \\
\hline Cx. tritaeniorhynchus & 0,21 & 0,08 & 0,02 \\
\hline Armigeres sp & 0,42 & 0,17 & 0,07 \\
\hline Aedes aegypti & 0,31 & 0,25 & 0,08
\end{tabular}

It shows that those mosquitoes can be the potential vectors of filariasis transmission in the Ketanggungan District. In Indonesia, Culex vishnui and Culex tritaeniorhyncus were reported as the vectors of Japanese encephalitis (JE). However, it does not rule out if these vectors became filariasis transmitter due to their high population density.

\section{Discussion}

Figure 1 shows that the highest biting activity by the Culex quinquefasciatus mosquito was around 1-2 PM local time. A study in Demak Regency, Central Java, stated the level of dominance of $C x$. quinquefasciatus was $65.92 \%$. Mosquito bite patterns were found every hour, with the peak at 1-2 PM. ${ }^{14}$

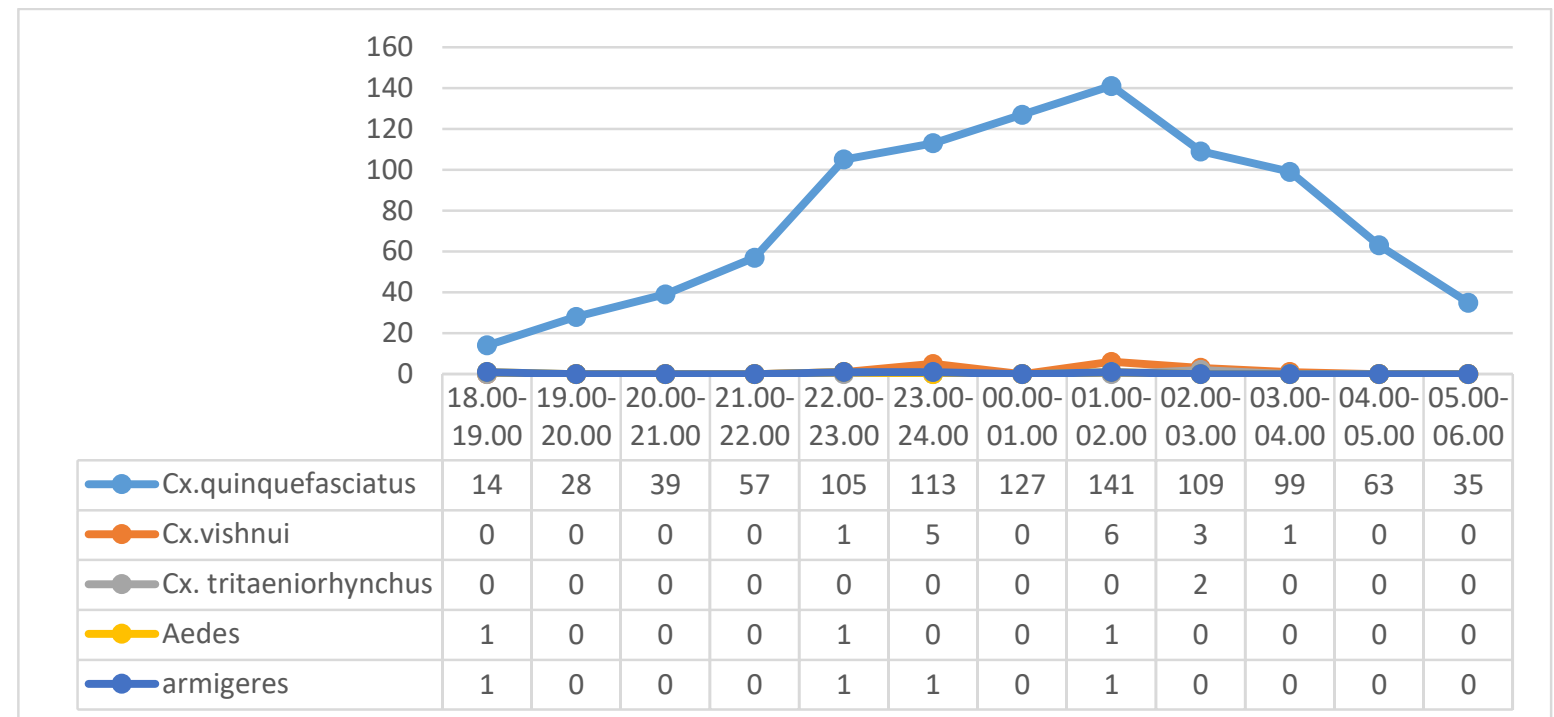

Figure 1. The Activity of Bitting Mosquitoes Caught Based on Bait People in Ketangggungan District, Brebes Regency

Species of Culex quinquefasciatus, known as urban-type bancrofti vector carriers, can transmit filariasis in the environments with filariasis. Other species such as Culex vishnui had biting activity around 1-2 PM, while culex tritaeniorhyncus found in Ketanggungan District had biting activity around 2-3 PM. Aedes aegypti mosquito bites in Ketanggungan District increased from 6-10 PM. Aedes aegypti species usually have a biting activity during the day, but it turns out that in Ketanggungan District, they are active as night insects (nocturnal). This is in line with research on the Pangandaran tourism market, which showed that Aedes aegypti had nighttime biting activity from 6 PM until 3 AM. A study in Kalimantan also showed that Aedes aegypti species has night-biting activity, from 6 PM until 6 AM. ${ }^{15}$ The biting activity of Armigeres $s p$ found in Ketanggungan District occurred at 6 PM-2 AM. 


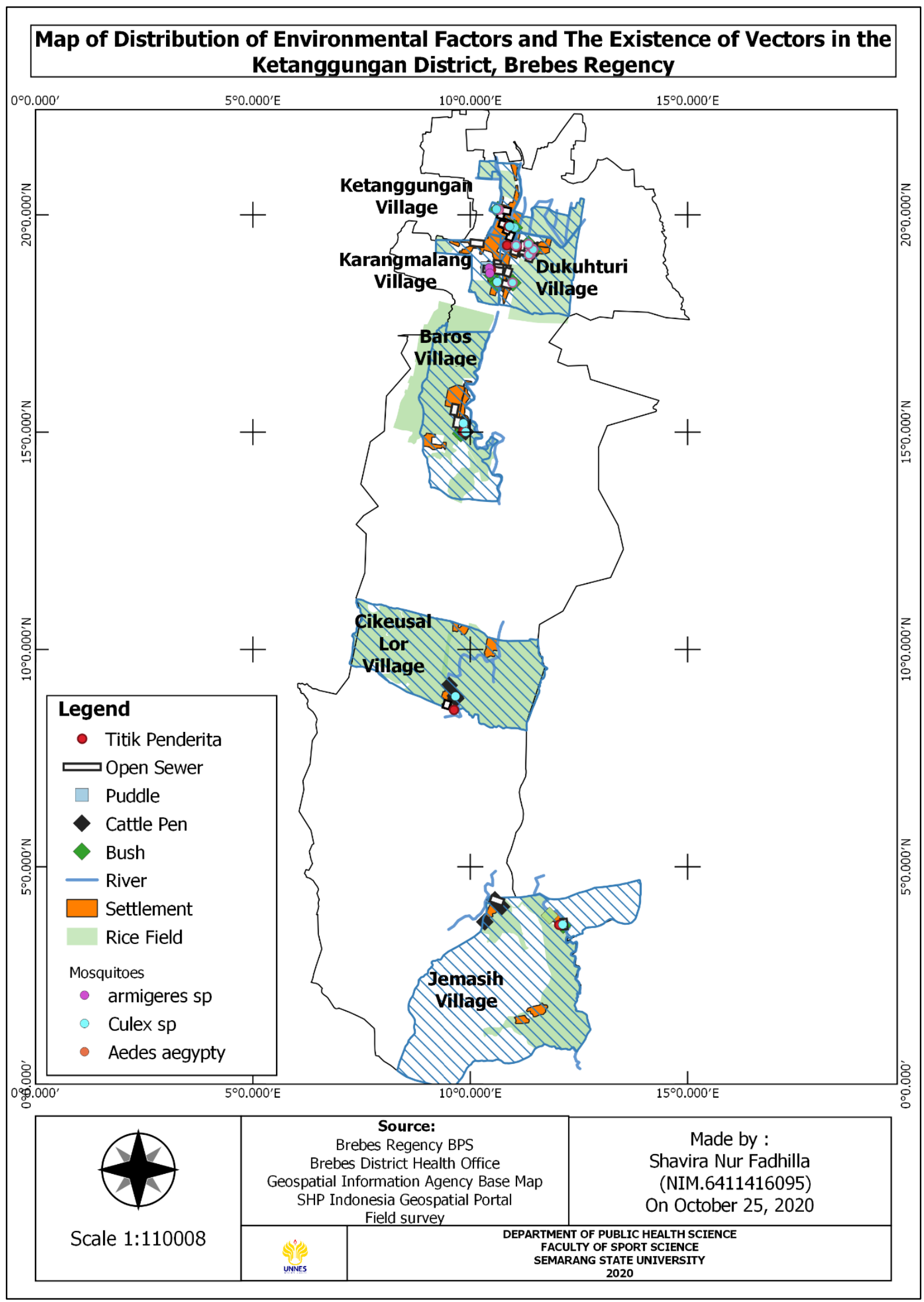

Figure 2. Distribution Map of Environmental Factors and the Existence of Vectors in Ketanggungan District, Brebes Regency 
This is in line with Yulidar's research, which found Armigeres sp was the confirmed mosquito as the vector of filariasis in West Aceh, Pidie, and East Aceh. ${ }^{16}$ Prastowo's research shows that the Armigeres species has biting activity throughout the night region from 6 PM to 6 AM. ${ }^{17}$

Figure 2 is an illustration of the distribution of environmental factors and the existence of vectors. The ecological factors described were the distribution of resting and captive breeding sites in Ketanggungan Regency. The spread of filariasis vectors in the transmission of filariasis is closely related to the mosquitoes' flight distance from the breeding grounds and resting places. In Figure 2, it can be seen that the mosquito distribution buffer zone can predict the extent to which mosquitoes can fly from the breeding areas and rest areas. The buffer zone analysis was determined based on the average flight distance of the mosquitoes. Based on the analysis, the genus of mosquitoes that can become the vectors of filariasis were Culex sp., Anopheles sp., Armigeres sp., and Aedes $s p$. The average flight distance for female mosquitoes from each genus: Culex ranges from 200 - 2000 m; Anopheles ranges from 300 - 500 m; Armigeres ranges from $1 \mathrm{~km}$; while Aedes sp ranges from 100 $\mathrm{m}^{8}$ Several mosquitoes' average flight distance as the vector for filariasis was assumed to be approximately 900 meters. ${ }^{18}$ Meanwhile, according to WHO, mosquitoes generally have the power to fly as far as 50-100 meters. The mosquito flight distance is also influenced by wind direction and speed. ${ }^{8}$

The buffer zone on the map shows the flight range of the mosquitoes originating from the resting place. Many resting places were found at a distance of $<100$ meters from 10 points of filariasis cases. Meanwhile, there are also many places of captivity found at a distance less than 100 meters from the point of filariasis cases totalling 24 points. Thus, houses with a distance of $<100$ meters from the case point have a greater risk of contracting filariasis as the flight distance of mosquitoes less than 200 meters has a significant chance of transmitting filariasis. $^{19}$

The results showed that the environmental factors favoured by the vector for breeding places and resting places mainly were around people with filariasis. So that the residents who live in Ketanggungan District, which is endemic to filariasis, are at risk of contracting filariasis. Furthermore, people living $<1000$ meters from the filariasis sufferer have the potential to contract filariasis. Thus, it is necessary to prioritize the prevention and control of filariasis transmission for these people. ${ }^{18}$

\section{Conclusion}

The dominant species of mosquito in Ketanggungan District, Brebes was $C x$. Quinquefasciatus, with a relative abundance value of $97.38 \%$ and a dominance level of $73.04 \%$. Environmental factors such as resting places (shrubs, and cattle pen) and breeding places (sewers, and fish ponds) were identified at all study sites. The most breeding places were found in Dukuhturi Village with 12 open sewers, 2 fish ponds and used boxes. The environmental conditions during the study had an average temperature of $19-31.7^{\circ} \mathrm{C}$ with $59-99 \%$ humidity. The condition was actually not the optimal conditions for the development of the mosquito population, but high humidity can increase the potential for transmission.

This study only focused on artificial environmental factors and described the environmental conditions during the study. Therefore, the next study has to focus on the natural environmental factors. Further research is sufficiently needed to run every month for one year to obtain data on mosquito diversity and environmental factors throughout the seasons of the year.

\section{Acknowledgement}

The authors would like to thank the Health Office of Brebes Regency for providing secondary data and permitting the primary data collection. We would like to express our sincere gratitude to Banjarnegara Research and Development Agency for their assistance during this research. We also gratefully thank you to 
Universitas Negeri Semarang for Research funding.

\section{References}

1. WHO. Epidemiology of Lymphatic Filariasis [Internet]. World Health Organization. 2021 [cited 2021 Feb 27]. Available from: https://www.who.int/newsroom/fact-sheets/detail/lymphaticfilariasis

2. Arsin AA. Epidemiologi filariasis di indonesia. I. Duhri AP, editor. Pusat Data dan Surveilans Epidemiologi Kementerian Kesehatan RI. Makassar: Masagena Press; 2016. $126 \mathrm{p}$.

3. Naito $H$. Eisai To Provide Diethylcarbamazine Citrate Tablets Free of Charge for Use in. Eisai Co. 2015;

4. Kementerian Kesehatan RI. Profil Kesehatan Indonesia Tahun 2019. Kemenkes RI. Jakarta: Kementerian Kesehatan RI; 2020. 198 p.

5. Jateng DP. Profil Kesehatan Provinsi Jawa Tengah Tahun 2019. 2020.

6. Dinkes Kabupaten Brebes. Profil Kesehatan Kabupaten Brebes Tahun 2019. Kabupaten Brebes: Dinas Kesehatan Kabupaten Brebes; 2019.

7. Departemen Kesehatan Republik Indonesia. Kunci Identifikasi Culex jentik dan Dewasa di Jawa. Jakarta: Ditjen PPM dan PLP; 1989.

8. WHO. Lymphatic Filariasis Practical Entomology. Global Programme to Eliminate Lymphatic Filariasis. 2013. 1-107 p.

9. Badan Pusat Statistik Kabupaten Brebes. Kabupaten Brebes Dalam Angka 2021. Kabupaten Brebes; 2021.

10. Badan Pusat Statistik. Kecamatan Ketanggungan Dalam Angka 2020. Kabupaten Brebes: Badan Pusat Statistik Kabupaten Brebes; 2020.

11. Tumbel, Axl N, Akili, Rahayu $\mathrm{H}$, Sondakh, Ricky C. Analisis Spasial Penyebaran Nyamuk Culex Spp di Kecamatan Paal Dua Kota Manado. Kesmas-Jurnal Kesehat Masy Univ
Sam Ratulangi. 2017;1-9.

12. Hestiningsih $R$, Puspitasari $E G$, Martini, Mawarni A, Purwantasari S. Populasi Culex Sp Sebagai Vektor Filariasis. Jurnal IImiah Stikes Kendal [Internet]. 2019;9(2):165-74. Available from: http://journal.stikeskendal.ac.id/inde x.php/PSKM/article/view/476

13. Anggraini TS, Cahyati WH. Perkembangan Aedes aegypti pada berbagai $\mathrm{pH}$ air dan salinitas air. Higeia J Public Heal Res Dev [Internet]. 2017;1(3):140-50. Available from: http://journal.unnes.ac.id/sju/index.p $\mathrm{hp} /$ higeia

14. Istianah S, Mulyaningsih B, Rahmah $S$. Culex quinquefasciatus With the Highest MHD as a Potential Filariasis Vector in Demak, Central Java , Indonesia , a Filariasis Endemic Area. Atl Press [Internet]. 2021;33(ICoSIHSN 2020):83-7. Available from: http://creativecommons.org/licenses /by-nc/4.0/.

15. Heni Prasetyowati, Rina Marina, Dewi Nur Khodijah, Mutiara Widawati TW. Larvae Survey and Nocturnal Activities of Aedes Spp . in Wisata Pangandaran Market. J Ekol Kesehat. 2014;13:33-42.

16. Yulidar. Populasi Nyamuk yang Berpotensi Sebagai Vektor Filariasis di Kabupaten Aceh Utara. Biotik. 2018;6(1):70-4.

17. Prastowo D, Anggraeni YM. Dinamika Populasi Nyamuk yang Diduga sebagai Vektor di Kecamatan Rowokele, Kabupaten Kebumen, Jawa Tengah. Vektora J Vektor dan Reserv Penyakit. 2014;4(2 Okt):83-97.

18. Heriyanto, B., Boewono, D.T., Widiarti, Boesri H, Widyastutu, U., Blondine, C.P. S, H., Ristiyanto, Pujiyanti, A., Alfiah S, Prastowo, D., Anggraini, Y.M., Irawan AS, Mujiyono. Atlas Vektor Penyakit di Indonesia. Jakarta: Kementerian Kesehatan Rl; 2011.

19. Asong, Arfan, I. S. Analisis Spasial Risiko Lingkungan Dengan Kejadian Filariasis Di Wilayah Kerja 
Puskesmas Sungai Asam

Kecamatan Sui Raya Kabupaten
Kubu Raya 2016. Jurnal Universitas

Muhammadiyah Pontianak; 2016. 